This is the peer reviewed version of the following article: Vrij A., and Granhag P. A. (2014) Eliciting Information and Detecting Lies in Intelligence Interviewing: An Overview Of Recent Research, Appl. Cognit. Psychol., 28, pages 936-944, doi:10.1002/acp.3071., which has been published in final form at http://onlinelibrary.wiley.com/doi/10.1002/acp.3071/full . This article may be used for noncommercial purposes in accordance with Wiley Terms and Conditions for Self-Archiving.

Eliciting Information and Detecting Lies in Intelligence Interviewing:

An Overview Of Recent Research

ALDERT VRIJ ${ }^{1}$

University of Portsmouth, UK

PÄR ANDERS GRANHAG

University of Gothenburg, Sweden

University of Oslo, Norway

Norwegian Police University College, Oslo, Norway

${ }^{1}$ Correspondence to: Aldert Vrij, Psychology Department, University of Portsmouth, King Henry Building, King Henry 1 Street, Portsmouth PO1 2DY, UK. E-mail: aldert.vrij@port.ac.uk 


\begin{abstract}
Traditional police-suspect interviews differ from intelligence interviews in several important ways, and these differences merit new research activities. This article presents an overview of recent and innovative research into eliciting infor- mation and cues to deceit in intelligence interviews, and discusses research into new domains including 'lying about intentions', 'undercover interviewing', and 'collective interviewing'. Although that research is still in its infancy, the findings reveal that truth tellers' and liars' answers can be distinguished from each other if the correct interview protocols are implemented, such as asking unexpected questions and introducing forced turn-taking. In addition, this new research also shows that the so-called Scharff tech- nique is more effective for eliciting human intelligence information compared with more traditional techniques.
\end{abstract}


Eliciting Information and Detecting Lies in Intelligence Interviewing:

\section{An Overview Of Recent Research}

Traditionally, forensic deception research focuses on police- suspect interviews (Evans et al., in press; Vrij \& Granhag, 2012; Vrij, Granhag, \& Porter, 2010). Although interest re- mains in this area, researchers increasingly examine informa- tion elicitation and deception detection in intelligence interviews. There are many differences between traditional police-suspect interviews and intelligence interviews. These differences merit new research activities, as much of the police-suspect deception research does not adequately ad- dress the various settings and factors that are relevant for intel- ligence efforts (Brandon, 2011; Evans, Meissner, Brandon, Russano, \& Kleinman, 2010; Loftus, 2011; Redlich, Kelly, \& Miller, in press; Russano, Narchet, \& Kleinman, in press; Russano, Narchet, Kleinman, \& Meissner, in press).

In this article, we concentrate on three differences between traditional policesuspect and intelligence interviews that have attracted research to date. We will review this research and summarise its findings. First, police--suspect interviews typically focus on lying about past activities. However, in relation to serious threats and terrorism, being able to discriminate between true and false accounts about future ac- tivities (e.g., intentions) is of paramount importance, as this addresses the issue of preventing criminal acts from occur- ring, including terrorist attacks. We will discuss this lying about intentions research. Second, police-suspect interviews are formal overt interviews that take place in a custodial set- ting. The threat of terrorism has led to an increased emphasis on the detection of deception in public spaces including country borders, security 
checkpoints, airports, bus termi- nals, train stations, shopping malls, and sport venues (Cooke \& Winner, 2008; Driskell, Salas, \& Driskell, 2012; Kimery, 2008). In such situations, investigators, and particularly those who are working in an undercover capacity, sometimes have good reason not to tell the interviewees that the 'chat' they have with them is, in fact, an interview. If interviewees would become aware that they are interviewed, it may reveal the undercover agent's identity and/or the interviewee might decide to fabricate information that might jeopardise a much larger operation. Alternatively, if an interviewee is aware that she or he is on the intelligence service' radar, it may hamper future investigation regarding this interviewee and/or the group she or he belongs to. For this reason, researchers have started to conduct deception research where undercover inter- viewers elicit information without the interviewee' awareness. We will discuss this undercover interviewing research. A third difference is that terrorist acts are often planned and executed by groups rather than individuals (Crenshaw, 1990; Soufan, 2011). For example, the terrorists travelled together to London to carry out the London 2005 bombings (official-documents. gov.uk/document/hc0506/hc10/1087/1087). Consequently, re- searchers have started to conduct research involving groups of truth tellers and liars who are interviewed together (collectively). We will discuss this collective interviewing research.

In intelligence interviews, it can be valuable to obtain information from suspects without them realising that they gave valuable information. This brings us to Hanns Joachim Scharff, a German interrogator of the German Luftwaffe (air force) in World War II (Toliver, 1997). Scharff's task was to interrogate American and British fighter pilots who were shot down and captured during their sorties over Europe. Those pilots 
generally liked to be interviewed by Scharff, as he was perceived as a real gentleman who did not put much pressure on them and with whom they thought they 'just had a chat' (Toliver, 1997). The same Scharff was very much liked by his German employers, as he extracted more valuable infor- mation from these pilots than many of his colleagues. Scharff's skill was to extract valuable information from his interviewees without them being aware that they pro- vided that information. Scharff, who was married to an British woman, gave lectures in the USA about his interrogation technique after World War II, but only re- cently have researchers begun to examine his technique. We will present the first findings of this research into the Scharff technique.

\section{Lying about intentions}

In recent years, psycho-legal scholars have started to conduct research on true and false intentions. Later, we will organise and present the efforts made so far. After introducing some pioneering work, we will review three stands of research: (i) unanticipated questions; (ii) anticipated questions; and (iii) strategic use of evidence (SUE). The first two strands are for situations where the interviewer does not have background information on the person questioned, and the third strand is for situations where there is such background information available (evidence).

Vrij, Granhag, Mann, and Leal (2011) conducted a study at an international airport using passengers as participants. Truth tellers were instructed to answer all interview ques- tions about their forthcoming trip truthfully. Liars were instructed to answer questions on their destination truthfully but were told to lie when answering questions about the purpose of their trip. Results showed an overall detection accuracy of 
truths and lies of approximately $70 \%$. In a follow-up study, the same team compared the deception detection accuracy for statements of intent and statements on past behaviour (Vrij et al., 2011). Military and police officers were given a mission to collect and deliver a pack- age. Intention related interviews were conducted before they began their mission, and interviews about their past actions were conducted after the mission was completed. Partici- pants were interviewed a total of four times, twice on their intentions and twice on their past actions. In half of the inter- views, they lied, and in the other half, they told the truth. Corroborating the findings of Vrij et al. (2011), the results showed an overall truth and lie accuracy of approximately $70 \%$ with regard to intentions. Regarding past activities, an overall truth and lie accuracy of approximately 55\% was found, a percentage typically found in lie detection about past activities (Bond \& DePaulo, 2006). These pioneering studies suggest that lies about intentions are detectable, but they offer little guidance in terms of theory or strategic questioning in order to elicit cues to deceit.

\section{Unanticipated questions}

A consistent finding in the deception literature is that liars prepare themselves for anticipated interviews. They do so by preparing possible answers to questions they expect to be asked (Granhag, Andersson, Strömwall, \& Hartwig, 2004; Granhag, Strömwall, \& Jonsson, 2003; Hartwig, Granhag, \& Strömwall, 2007; Vrij et al., 2009). This strategy of preparing answers for possible questions makes sense. Planning makes lying easier, and planned lies typically con- tain fewer cues to deceit than spontaneous lies (DePaulo et al., 2003). However, preparing will be fruitful only if liars correctly anticipate which questions will be asked. Investiga- tors can exploit this limitation by asking unanticipated ques- tions. Although liars can refuse to answer unanticipated questions by saying 'I 
don't know' or 'I can't remember', such responses will create suspicion if these questions are about central aspects of the target event. A liar, therefore, has little option other than to fabricate a plausible answer on the spot, which is cognitively demanding. For liars, expected questions should be easier to answer than unanticipated questions, because liars can give their planned and rehearsed answers to the expected questions, but they need to fabricate answers to the unexpected questions. The difference liars experience in cognitive load while answering these two sets of questions should become evident in their verbal responses. In contrast, the levels of cognitive load that truth tellers experience while answering anticipated and unanticipated questions should not be too different from each other, and they should produce more comparable answers to the anticipated and unanticipated questions than liars.

There are many reasons for why a particular question posed during an interview will be perceived as unanticipated. First, the question may target a domain that the interviewee anticipates to be questioned about (e.g., a forthcoming trip) but stretches beyond the set of questions she or he is expecting to be asked (e.g., about transportation from the airport). Second, the question may target a domain that is unanticipated (e.g., the planning phase of the forthcoming trip where the stated intentions were formed). Research on both these types of unanticipated questions will be reviewed later. In connection to this, one should note that there is at least one other form of unanticipated question that can be useful in deception detection contexts. That is, where the question as such is expected ('Can you please describe the restaurant where you had dinner last night!'), but where the response format is unanticipated ('Please make a sketch of the restaurant?') (for an example, see Vrij et al., 2009). 
Warmelink, Vrij, Mann and Granhag (in press), Warmelink, Vrij, Mann, Jundi and Granhag (2012) exam- ined the effects of asking unanticipated questions about the stated intentions. In brief, truth tellers and liars were interviewed about an alleged forthcoming trip. Anticipated questions about the purpose of the trip (e.g., 'What is the main purpose of your trip?') were followed by, which a pilot study indicated, unanticipated questions about transport (e. g., 'How are you going to travel to your destination?'), plan- ning ('What part of the trip was easiest to plan?'), and the core event ('Keep in mind an image of the most important thing you are going to do on this trip. Please describe this mental image in detail?'). Liars, compared with truth tellers, gave significantly more detail to the expected questions and significantly less detail to the unexpected questions.

Next, we will discuss research on the effects of posing ques- tions that target an unanticipated domain. By summarising the work on true and false intentions, it is possible to distinguish between three lines of research. The first line examines the effect of asking questions about the planning phase. Research by Sooniste, Granhag, Knieps, and Vrij (2013) showed that questions about the planning phase are much less anticipated than questions about the intentions per se. Furthermore, and in line with the reasoning outlined earlier, truth tellers and liars provided similar answers to questions about their intentions (anticipated questions) but different answers to questions about the planning phase (unanticipated questions), with truth tellers providing more detailed answers to the unanticipated questions than liars (Sooniste et al., 2013).

In two follow-up studies, this approach has been success- fully extended to small cells of suspects. In those studies, small groups of truth tellers plan to carry out a task and 
are instructed to (if intercepted) answer questions about the task truthfully. Small groups of liars plan to carry out an illegal task and are asked to (if intercepted) conceal this in a subse- quent interview by pretending that they are about to carry out an innocent task. All participants are intercepted before having the chance to carry out their planned tasks, and they are all interviewed separately. In essence, questions about the plan- ning phase produced larger differences between truth tellers and liars in terms of consistency within the groups than ques- tions about intentions (Mac Giolla \& Granhag, in press; Sooniste, Granhag, Strömwall, \& Vrij, in press). In a recent study, the same team of researchers successfully used a memory-enhancing technique (the Cognitive Interview) to fur- ther magnify the differences between truth tellers' and liars' answers to the unanticipated questions targeting the planning phase (Sooniste, Granhag, Vrij, \& Strömwall, 2014).

The second line of research focuses on the quality of the plans made. In brief, as truth tellers are typically more moti- vated to plan their intentions than liars, one may predict that they would produce better plans. In line with this assump- tion, Mac Giolla, Granhag, and Liu-Jönsson (2013) found more markers of good planning behaviour (e.g., effective time allocation, implementation intention related uttering, and likelihood to refer to potential problems) in truth tellers' statements about the future than in liars' statements. Relat- edly, in a recent study, participants were told either that they were to partake in an argument creation task (true intention) or that they were to lie about their intentions to partake in the task (false intention). Those with a true intention reported to had more, and also more distracting, task-related thoughts than those with a false intention (Mac Giolla, Granhag, \& Ask, 2014, Experiment 1).

The third line of research concerns the concept of episodic future thought (EFT) 
and mental images. EFT refers to our ability to pre-experience future events through mental simulation, with a strong focus on visual imagery (Szpunar, 2010). In brief, just as planning is a typical feature of inten- tions, EFTs are a typical — and often automaticfeature of planning. Consequently, as truth tellers are more likely to engage in detailed planning, it follows that truth tellers should have EFTs related to their intentions to a greater extent than liars. In a larger project, Knieps (2013) examined this assumption by instructing truth tellers to plan a trip to a nearby shopping mall, while liars used a shopping trip as a cover story to mask their criminal intentions. Overall, the basic assumption received strong empirical support (e.g., Granhag \& Knieps, 2011; Knieps, Granhag, \& Vrij, 2013a, 2013b). Specifically, self-report measures show that truth tellers are much more likely than liars to have EFTs. Translated into an investigate interview setting, the series of studies show that more truth tellers than liars report experiencing a mental image during the planning phase (Knieps, 2013). Differently put, if the suspect did not report having a mental image activated during the planning phase, he or she was most likely to be lying about his or her stated intentions. Caution might be warranted, as the ability to establish and remember mental images of the future might vary across individuals. On the other hand, pre-experiencing the future in the form of mental images is a fundamental aspect of human cognition and a normal, day-to-day activity (Schacter, Addis, \& Buckner, 2008).

\section{Anticipated questions}

The work reviewed earlier shows that asking only anticipated questions will make it difficult to discriminate between persons telling the truth about their future intentions and persons who lie about their future intentions. However, we do not argue that 
anticipated questions are of no value to dis- criminate between true and false intentions. There is research from social cognition on goal-directed behaviour that can be used as the basis for predicting differences between statements expressing true and statements expressing false intentions. Specifically, Gollwitzer and his colleagues pro- posed the theory of implementation intentions that specifies the behaviour that will be performed in service of the goal (Gollwitzer, 1999). Particularly significant are the so-called 'if-then' plans ('If the butcher is out of beef, I will buy chicken'), that will assist in accomplishing goals (e.g., Sheeran, Milne, Webb, \& Gollwitzer, 2005). In essence, implementation intentions specify (among other things) how the stated goal will be achieved. Importantly, a person who has no intention of pursuing a stated goal is unlikely to form an intention implementation that spells out how the goal will be pursued (e.g., Sheeran et al., 2005).

In support of this assumption, Sooniste et al. (2013) found that truth tellers' answers were more characterised by information (utterances) pertaining to how the stated intention would be reached compared with liars' answers. In contrast, liars' answers were more characterised by information pertaining to why the stated goal had to be pursued. The latter finding was explained by drawing on research showing that persons who have decided to lie about their intentions prepare ready-made answers to anticipated questions that are geared towards why they have to do what they (falsely) claim that they will do (Clemens, Granhag, \& Strömwall, 2013). Research on social cognition may provide researchers with new and theoretically sound markers that are worth ex- amining in future studies aimed at discriminating between true and false intentions.

\section{Strategic use of evidence}


The SUE technique is an example of a technique emerging from research on strategic ways of interrogating suspects in or- der to elicit cues to truth and deception (Vrij \& Granhag, 2012). Ultimately, the SUE technique rests on the theoretically driven assumption that guilty suspects and innocent suspects enter interrogations in a different mental state (Hartwig, Granhag, \& Luke, 2014). There is empirical support that these different mental states result in diverse strategies with respect to providing critical information. In brief, guilty suspects (falsely denying guilt) use more avoidance, aversive, or denial strategies, whereas innocent suspects (truthfully denying guilt) neither avoid nor escape but use more forthcoming verbal strategies (e.g., Hartwig et al., 2007; Kassin, 2005; Strömwall, Hartwig, \& Granhag, 2006). In principle, there are three groups of SUE tactics: (i) evidence tactics; (ii) question tactics; and (iii) disclosure tactics (Granhag \& Hartwig, 2015). The evidence tactics are primarily used to assess the evidence in the planning phase, the question tactics are used to systemati- cally exhaust the alternative explanations that a suspect may have to account for the evidence, and the disclosure tactics are used to disclose the evidence in the most effective manner (i.e., to maximise the diagnostic value of the evidence). Impor- tantly, all these tactics are derived from the conceptual frame- work underlying the SUE technique (Granhag \& Hartwig, 2015; Hartwig et al., 2014).

The SUE technique has proven successful in eliciting cues to deception in single suspects (Hartwig et al., 2006) and small groups of suspects (Granhag, Rangmar, \& Strömwall, in press), in adults (Hartwig, Granhag, Strömwall, Wolf, \& Vrij, 2011) and children (Clemens et al., 2010), as well as for suspects lying about their past actions (Hartwig, Granhag, Strömwall, \& Vrij, 2005) and suspects lying about their intentions 
(Clemens, Granhag, \& Strömwall, 2011). For a recent review of the empirical findings on the SUE technique, including the first meta-analysis of the technique, see Hartwig et al. (2014).

In sum, although research on true and false intentions is a new area within the broader field of 'deception detection', it already offers a number of different tactical approaches. While it is clear that these approaches need to be developed further, this is not the same as arguing that the knowledge obtained from the first wave of studies is without practical implications. For example, based on our own extensive travel experience, we have the impression that throughout the world, immigration officers mainly ask anticipated questions when quizzing passengers at airport border con- trols (e.g., questions on the purpose of the trip). In all likeli- hood, they pay attention to the amount of detail passengers give, with the richer, more detailed accounts being perceived as more believable (e.g., Bell \& Loftus, 1989). In brief, and as described earlier, potential wrongdoers will be well equipped to answer such questions in detail and subse- quently will make an honest impression on immigration officers. The interview protocols used in border control work should draw on the fact that criminally inclined individuals rarely expect the unexpected.

\section{UNDERCOVER INTERVIEWING}

Undercover interviewing can be employed when an investigator does not want the interviewee to be known that she or he is being interviewed. Undercover interviewing has disadvantages and advantages compared with formal overt interviews. Starting with the disadvantages, interview tools that have shown to facilitate lie detection, such as 
discussing evidence ('Show me your ticket?’; e.g., Granhag \& Hartwig, 2008; Granhag, Strömwall, \& Hartwig, 2007) or imposing cognitive load on interviewees by asking them to recall a story in reverse order ('Please tell me how you went from your home to the train station but do that in reverse order so start from here and go back to your home?'; e.g., Vrij, Leal, Mann, \& Fisher, 2012), cannot be employed without making the suspect suspicious about the questioner's motives. For that reason, long and in-depth interview protocols are often not possible either.

The advantage of undercover interviewing is that some techniques can be introduced that will discriminate between truth tellers and liars that may not work as well in overt interviews. These techniques relate to exploiting (i) liars' tendency to withhold information that they believe could be potentially incriminating (Hartwig, Granhag, Strömwall, \& Kronkvist, 2006; Hartwig et al., 2005) and (ii) liars' tendency to be less cooperative than truth tellers (DePaulo et al., 2003). Withholding information is related to the basic forms of human behaviour avoidance and escape (Carlson, Buskist, \& Martin, 2000; Granhag \& Hartwig, 2008). In terms of self-regulation, this is viewed as a manner of establishing control— by avoiding the aversive event altogether (Granhag \& Hartwig, 2008). From DePaulo et al.'s meta-analysis of cues to deceit, it emerged that liars are typically less cooperative than truth tellers. To explain this, DePaulo and colleagues argued that liars often experience more negative affect than truth tellers, and this could make them more reluctant to engage in conversations, leading to less cooperation.

The undercover interviewer could exploit liars' tendency to be aversive and/or uncooperative by inviting suspects to engage in an apparently innocent activity that establishes their presence in a certain place at a certain time. Liars' tendency to be 
aversive and/or uncooperative may result in greater reluctance to comply with this seemingly innocuous compliance request. Vrij, Mann, Jundi, Hope, and Leal (2012) tested this assumption. Liars were instructed to run a crime-related reconnaissance mission to a nearby island and were further instructed to generate as an innocent cover story that they were going to visit the island as a tourist to hide their criminal intentions. On arrival at the hovercraft terminal, an undercover agent, acting in the role of either a doctoral student or an amateur photographer, approached the liars and asked apparently innocuous questions about their forthcoming trip, including whether they would mind having a photo taken that he could put up on his website. Actual tourists using the hovercraft terminal served as a con- trol group. Significantly fewer liars $(60 \%)$ than truth tellers $(81 \%)$ gave permission to be photographed. Importantly, participants did not find it odd to be approached by the undercover interviewer and did not think his questions were odd (as examined in a post-interview questionnaire). In other words, employing an undercover interviewer in this way revealed differences between truth tellers and liars, and did not raise suspicion.

The tendency to be aversive and/or uncooperative can also be exploited in a different way. When planning large scale incidents or bombing campaigns, terrorists often conduct reconnaissance missions to identify key targets (Soufan, 2011). This may include taking photographs of potential target locations. Identifying an effective real-time method to distinguish between genuine photographers and those with more sinister intent may be beneficial and could avoid instances such as in London where the police asked tourists to delete their photos taken as a precautionary counter- terrorist measure (Weaver \& Dodd, 2009). Undercover interviewing could shed light on whether an individual has 
criminal intentions, as Jundi, Vrij, Mann, Hillman, and Hope (under review) found. In their study, participants were asked to take photographs on a square for tourist or terrorist purposes. The 'terrorists' were also asked to take pictures for tourist purposes as a cover story. On the square, a mime artist was present who comically impersonated people as they passed through the square. As the participant was about to leave the square after taking their photographs, the mime artist approached the participant and asked if she or he had photographed him. If she or he answered 'yes', he asked if he could see the photograph, and if she or he said 'no' or that they weren't sure, he asked if he could check as he thought he was in the background when the participant was taking photographs. Results revealed that similar percentages of 'tourists' and 'terrorists' (74\%) had taken at least one picture of the mime artist. The difference appeared in the willingness to show these pictures to him. Truth tellers (36\%) were more likely than liars $(8 \%)$ to tell the mime artist that they had taken a picture of him, and truth tellers $(60 \%)$ were significantly more likely than liars $(20 \%)$ to allow him to see their photographs.

Liars' avoidance to be linked with incriminating evidence can also be exploited in undercover interviews to establish evidence. Liars often view the presence of witnesses as potentially incriminating because witnesses can serve as additional information sources against which investigators can check the veracity of the liars' statement (Granhag \& Hartwig, 2008; Nahari, Vrij, \& Fisher, 2012, in press). Therefore, a suspect could first be interviewed by an under- cover interviewer about an apparently innocuous activity. Later on, the suspect could be interviewed about the time period that included the interaction with the undercover interviewer by a second interviewer who is aware of the undercover interview but does not reveal this knowledge to the suspect. Liars may be 
more reluctant than truth tellers to report the interaction with the undercover interviewer because of their tendency to avoid reporting information that they fear may be potentially incriminating. In Jundi, Vrij, Hope, Mann, and Hillman (2013), truth tellers and liars undertook a mission in a park. They went to the park for different reasons and carried out somewhat different activities, but both missions included taking pictures of the animals at the animal enclosure. Liars were instructed that if they were asked about their activities, they should conceal their true reason for visiting the park and to pretend to visit the park for the same reason as truth tellers. At the animal enclosure, truth tellers and liars were interviewed by an undercover interviewer posing as a City Council employee who asked them about their activities at the animal enclosure and park. After completing the mission, participants had a formal overt interview with a second interviewer. When asked in the initial free recall question to give a detailed account of the mission, more truth tellers $(42 \%)$ than liars $(9 \%)$ mentioned the undercover interviewer. When specifically asked what they could see from the animal enclosure, again more truth tellers (17\%) than liars $(0 \%)$ spontaneously mentioned the undercover interviewer. Because taking pictures of the animals (the activity the participants carried out when approached by the undercover interviewer) was both part of the truth tellers' and liars' missions, liars could have been honest and could have said that they had spoken to someone at the animal encounter, yet they were reluctant to do so.

In sum, the undercover studies carried out to date showed that liars are more aversive and/or more uncooperative than truth tellers. Which of these two tendencies (being aversive or uncooperative) explains the results best is impossible to de- cipher from the research findings available to date, because both tendencies predict the same 
outcome. Further research could shed light on how to explain the current set of results. This, however, does not take away that liars' tendency to be aversive and/or uncooperative can be easily demonstrated in undercover interviews. Perhaps, a reason why it can be easily demonstrated is that liars, being unaware that they are interviewed, do not attempt to mask their tendency to be aver- sive or uncooperative. This may be different in overt inter- views. Liars may fear that being aversive or uncooperative looks suspicious (Strömwall, Granhag, \& Hartwig, 2004) and therefore may be more cooperative in overt interviews than in undercover interviews.

\section{COLLECTIVE INTERVIEWING}

People often commit crimes or carry out reconnaissance missions in groups (Crenshaw, 1990; Soufan, 2011). In police-suspect interviews, suspects are typically interviewed individually and immediately separated from their group members (Kassin \& Gudjonsson, 2004). This is reflected in deception research. The number of studies that have exam- ined groups of truth tellers and liars is small, but in these studies, the group members are typically interviewed separately (Granhag et al., 2003; Meijer, Bente, BenShakhar, \& Schumacher, 2013; Meijer, Smulders, \& Merckelbach, 2010; Vrij et al., 2009). In intelligence settings, there are situations whereby it would be more suit- able, timely, and convenient to interview group members simultaneously, for example, at border check points where cars containing several people are checked. Interviewing suspects collectively has as an advantage that investigators can pay attention to communication cues (how do the suspects interact with each other), which contain potential signs of deceit. 
When pairs of truth tellers recall a jointly experienced event, they may communicate substantially with each other in an attempt to collectively recall all the details they know (e.g., transaction information search; Hollingshead, 1998). They therefore may add information to each other's stories, make corrections or interpret each other, or pose questions to one another to tap into the other's memory domain. In contrast, liars will not have a joint experience to recall. They may provide their prepared answers to anticipated questions, or if the questions were not anticipated, one person may take the lead and the other person may simply agree with what is said. This is a far less interactive approach than the truth tellers' approach. Indeed, in the three collective interviewing experiments to date, the pairs of liars made fewer additions, corrections, and interruptions than the pairs of truth tellers, and posed more questions to each other (Driskell et al., 2012; Jundi, Vrij, Hope, Mann, \& Hillman, 2013; Vrij, Mann et al., 2012). Also, because truth tellers communicate more with each other, they also tend to gaze more at each other and less at the interviewer than liars do (Jundi, Vrij, Mann, et al., in press).

In the UK, one way to obtain British citizenship is to marry a British citizen. Sometimes, a non-British citizen tries to exploit this by setting up a sham marriage with a British citizen who may get paid for this service. In order to assess whether marriages are real or a sham, in the UK, couples are interviewed simultaneously as part of the procedure. Communication cues have the potential to discriminate between truth tellers and liars. Transactive memory theory proposes that people in close relationships have a specialised memory system or 'division of labour' for encoding, storing, and retrieving information (Hollingshead, 1998; Wegner, 1987). People who are actually in a close relationship know what they are to remember as well as what the other person in the 
relationship is to remember. This becomes evident when they discuss jointly experienced events, and as a result, compared with fictitious couples, real couples pose more questions to one another to check or find out information (e.g., 'Was I working that day?'), handing over remembering responsibility more (e.g., 'You remember this better than me, why don't you explain it'; 'Do you want to explain this? I know you like telling this story'), and finishing each other's sentences more (e.g., one member starts saying 'We went on the banana boat and...', the second member continues '... and we fell off into the cold water').

Vernham, Vrij, Mann, Leal, and Hillman (2014) tested the transactive memory theory in a lie detection context. In their experiment, truth tellers were real couples who had been in a relationship for at least 1year and cohabiting. Lying pairs were friends who pretended to be in a relation- ship for at least 1year and cohabiting. All couples were interviewed together about their 'real' or 'fictitious' relation- ship. It was found that truth-telling pairs posed questions to one another, provided cues to one another, handed over remembering responsibility, and finished each others' sentences significantly more than lying pairs, supporting the idea that real couples have a transactive memory system, unlike pretend couples. Based on the finishing each other sentences cue in particular, many truth tellers $(84 \%)$ and liars $(91 \%)$ were classified correctly.

Collective interviews are further suitable for implementing an 'imposing cognitive load' interview technique, such as 'forced turn taking'. When recalling information as a pair or group, the group members interact with each other resulting in a naturally occurring turn-taking pattern - the pattern in which one person speaks then stops, and then another person continues then stops, etc. (Sacks, Schegloff, \& Jefferson, 
1974). Forced turn-taking occurs when the interviewer stops whichever a member of the pair was recalling after a short period of time (say 15 seconds) and then asks the other member in the pair to continue from the point in which their partner was stopped. Forced turn-taking is cognitively demanding because it takes away members' ability to choose who an- swers each of the questions, removing the effects of any dominant characters who tend to speak more frequently (Hung et al., 2007), and removes any retrieval strategy adopted by the pairs (Basden, Basden, Bryner, \& Thomas, 1997). Finally, interrupting somebody's turn has been found to violate the natural flow of recall, increase anxiety, and inhibit the ability of the individual to then continue with their turn (Coates, 2004).

In Vernham et al.'s (2014) forced turn-taking experiment, truth tellers were real couples who had been in relationship for at least 1 year and cohabiting, whereas lying pairs were friends who pretended to be in a relationship for at least 1year and cohabiting. All 'couples' were interviewed together in their pairs about their real or fictitious relation- ship. Truth-telling pairs were more likely to continue the story after being told to turn-take, whereas lying pairs more often repeated what their partner last said before continuing. In addition, lying pairs waited before speaking after being told to turn-take significantly more than truth-telling pairs. Liars' tendency to wait longer before answering and, when they started speaking, to first repeat what their partner has said makes clear that they found forced turn-taking more difficult than truth tellers.

In sum, although only a few collective interviewing deception studies have been carried out to date, the findings of these studies revealed that collective interview has poten- tial to become a successful method to detect deceit. Members of truth-telling 
groups communicate more with each other than members of lying groups when asked to jointly recall an event, and truth tellers handle the request to turn-take smoother than liars do.

\section{THE SCHARFF TECHNIQUE}

The gathering of human intelligence (HUMINT) is at the core of both traditional law enforcement work and efforts aimed at countering terrorism. Human intelligence is one of many different forms of intelligence, and it is perhaps best described as the gathering of information by means of an interaction between two or more individuals (e.g., Justice, Bhatt, Brandon \& Kleinman, 2010). Hence, one would expect to find guidance from modern psychological research on how to effectively gather human intelligence, but this is not the case. In fact, the body of modern research on techniques aimed at gathering human intelligence is very meagre. Granhag and his colleagues set out to remedy this and have recently completed the first series of studies exam- ining the comparative effectiveness of human intelligence gathering techniques. Specifically, they compared the so- called Scharff technique against the Direct Approach technique. The Scharff technique draws on principles used by Hanns Scharff, the highly successful interrogator working for the German Luftwaffe during World War II (Toliver, 1997). In brief, the Scharff technique, as tested in the studies cited later, is conceptualised into four different tactics (Granhag, 2010): (i) a friendly approach; (ii) not pressing for information; (iii) playing on the 'illusion of already knowing it all'; and (iv) working with confirmations/disconfirmations (instead of asking direct questions). The Direct Approach is based on a combination of open-ended and specific questions, and is recommended as the standard technique by the U.S. Army Field Manual (FM 2-22.3, Human Intelligence 
Collec- tor Operations). Recent surveys confirm that the Direct Approach is indeed one of the most commonly used human intelligence gathering techniques (e.g., Redlich, Kelly, \& Miller, 2011).

All studies cited later employed an experimental paradigm in- troduced by Granhag, Cancino Montecinos, and Oleszkiewicz (2013), mirroring some central features of a typical HUMINT interaction. In essence, each participant (source) received incomplete information about an upcoming terrorist attack and was instructed to appear cooperative in a forthcoming interview. They were instructed to achieve this by striking a balance be- tween not revealing too much but also not too little information in the interview.

The studies show promising results in favour of the Scharff technique. First, the sources interviewed with the Scharff tech- nique reveal more new information compared with the sources interviewed with the Direct Approach (e.g., Oleszkiewicz, Granhag, \& Kleinman, in press; May, Granhag, \& Oleszkiewicz, 2014, when combining the two versions of the Scharff technique). Second, the sources interviewed with the Scharff technique were less accurate in establishing which in- formation the interviewer was after (e.g., Granhag et al., 2013; May et al., 2014). Third, the studies show that a large majority of the sources interviewed by the Scharff technique believed they had revealed less new information than was actually the case, whereas the majority of the sources interviewed with the Direct Approach believed they had revealed more new in- formation than was actually the case (Oleszkiewicz, Granhag, \& Cancino Montecinos, in press; Oleszkiewicz et al., in press; May et al., 2014). In other words, the Scharff technique leads the source to underestimate how much new information she or he revealed during the interview, 
whereas the Direct Approach leads the source to overestimate how much new information she or he revealed. A source underestimating how much information she or he revealed during the interac- tion is an important indicator of an effective human intelligence gathering technique and was the trademark of Hanns Scharff's technique (Toliver, 1997). Importantly, in a recent study, Granhag, Oleszkiewicz, and Kleinman (2014) showed that the aforementioned findings also hold for (i) sources who are more or less willing to provide information during an interview and (ii) sources who hold more or less information (i.e., sources who are more or less capable of providing information).

In sum, the first series of studies showed that the Scharff technique is a promising tool for gathering information in intelligence settings. However, we would like to point out that this strand of research is still in its infancy and that more research is required to obtain a full picture of the success of the technique. We believe that future research on different aspects of the Scharff technique, and using a more diverse sample of participants and scenarios, will make the picture more complete.

\section{CONCLUSION}

In this article, we argued that traditional police-suspect inter- views differ from intelligence interviews in several important ways and that these differences merit new research activities, as much of the current deception research literature does not adequately address the various settings and factors that are relevant for terrorism. We discussed numerous strands of innovative research in various new domains, including lying about intentions, undercover interviewing, and collective interviewing. Research activities in these strands of research are still in their infancy, but the results of the studies 
consis- tently reveal that differences between truth tellers and liars emerge in intelligence interviews if the appropriate interview protocols are used, such as the unexpected questions approach, forced turn-taking, and the Scharff technique. We hope that this article will inspire academics in their thinking about how to effectively interview suspects in intelligence interviews, and we encourage these academics to carry out research in this important and innovative line of interviewing. 


\section{REFERENCES}

Basden, B. H., Basden, D. R., Bryner, S., \& Thomas III, R. L. (1997). A comparison of group and individual remembering: Does collaboration disrupt retrieval strategies? Journal of Experimental Psychology. Learn- ing, Memory, and Cognition, 23, 1176-1189. DOI: 10.1037/0278- 7393.23.5.1176.

Bell, B. E., \& Loftus, E. F. (1989). Trivial persuasion in the courtroom: The power of (a few) minor details. Journal of Personality and Social Psychology, 56, 669679.

Bond, C. F., \& DePaulo, B. M. (2006). Accuracy of deception judgements. Personality and Social Psychology Review, 10, 214-234.

Brandon, S. (2011). Impacts of psychological science on national security agencies post-9/11. American Psychologist, 66, 495-506.

Carlson, N. R., Buskist, W., \& Martin, G. N. (2000). Psychology: The sci- ence of behaviour. Harlow, UK: Allyn \& Bacon.

Clemens, F., Granhag, P. A., \& Strömwall, L. A. (2011). Eliciting cues to false intent: A new application of strategic interviewing. Law and Human Behavior, 35, 512522. doi:10.1007/s10979-010-9258-9

Clemens, F., Granhag, P. A., \& Strömwall, L. A. (2013). Counter-interrogation strategies when anticipating questions on intentions. Journal of Investigative Psychology 
and Offender Profiling, 10, 125-138. doi:10.1002/jip.1387

Clemens, F., Granhag, P.A., Strömwall, L.A. Vrij, A., Landström, S., Roos af Hjelmsäter, E, \& Hartwig, M (2010). Skulking around the dinosaur: Eliciting cues to children's deception via strategic disclosure of evidence. Applied Cognitive Psychology, 24, 925-940.

Coates, J. (2004). Women, men and language: A sociolinguistic account of gender differences in language (3rd edn). Longman: Harlow.

Cooke, N. J., \& Winner, J. L. (2008). Human factors of homeland security. In D. A. Boehm-Davis (Ed.), Reviews of human factors and ergonomics, volume 3 (pp. 79110). Santa Monica, CA: Human Factors and Ergonomics Society.

Crenshaw, M. (1990). Questions to be answered, research to be done, knowledge to be applied. In W. Reich (Ed.), Origins of terrorism: Psychologies, ideologies, theologies, states of mind (pp. 247-260). Cambridge, England: Cambridge University Press.

DePaulo, B. M., Lindsay, J. L., Malone, B. E., Muhlenbruck, L., Charlton, K., \& Cooper, H. (2003). Cues to deception. Psychological Bulletin, 129, 74-118.

Driskell, J. E., Salas, E., \& Driskell, T. (2012). Social indicators of decep- tion. Human Factors: The Journal of the Human Factors and Ergonom- ics Society, 54, 57712588.

Evans, J. R., Houston, K. A., Meissner, C. A., Ross, A. B. Ross, LaBianca, J. R., 
Woestehoff, S. A., \& Kleinman, S. M. (in press). An empirical eval- uation of intelligence-gathering interrogation techniques from the United States Army Field Manual. Applied Cognitive Psychology.

Evans, J. R., Meissner, C. A., Brandon, S. E., Russano, M. B., \& Kleinman, S. M. (2010). Criminal versus HUMINT interrogations: The importance of psychological science to improving interrogative practice. Journal of Psychiatry \& Law, 38, 215-249.

Gollwitzer, P. M. (1999). Implementation intentions: Strong effects of simple plans. American Psychologist, 54, 493-503.

Granhag, P. A. (2010). The Scharff-technique: Background and first scien- tific testing. Professional Development Seminar, High-value Detainee Interrogation Group (HIG, FBI). Washington, D.C.

Granhag, P.A., Andersson, L.O., Strömwall, L.A., \& Hartwig, M. (2004). Imprisoned knowledge: Criminals' beliefs about deception. Legal and Criminological Psychology, 9, 103-119.

Granhag, P. A., Cancino Montecinos, S., \& Oleszkiewicz, S. (2013). Eliciting intelligence from sources: The first scientific test of the Scharff technique. Legal and Criminological Psychology. doi: 10.1111/ lcrp.12015.

Granhag, P.A., \& Hartwig, M. (2008). A new theoretical perspective on deception detection: On the psychology of instrumental mind-reading. Psychology, Crime \& Law, $14,189-200$. 
Granhag, P.A., \& Hartwig, M. (2015). The Strategic Use of Evidence (SUE) technique: A conceptual overview. In P. A. Granhag, A. Vrij, B. Verschuere (Eds), Deception detection: Current challenges and cognitive approaches. (pp 231-251). Chichester, UK: John Wiley.

Granhag, P. A., \& Knieps, M. (2011). Episodic future thought: Illuminating the trademarks of forming true and false intentions. Applied Cognitive Psychology, 25, 274280. doi:10.1002/acp.1674

Granhag, P.A. Oleszkiewicz, S, \& Kleinman, S.M. (2014). Eliciting intelligence from sources more or less willing and informed: Further tests of the Scharff-technique. Manuscript submitted for publication.

Granhag, P.A., Rangmar, J., \& Strömwall, L.A. (in press). Small cells of suspects: Eliciting cues to deception by strategic interviewing. Journal of Investigative Psychology \& Offender Profiling.

Granhag, P. A., Strömwall, L. A., \& Hartwig, M. (2007). The SUE tech- nique: The way to interview to detect deception. Forensic Update, 88, January, 25-29.

Granhag, P.A., Strömwall, L.A., \& Jonsson, A.C. (2003). Partners in crime: How liars in collusion betray themselves. Journal of Applied Social Psy- chology, 4, 848-867.

Hartwig, M., Granhag, P.A., \& Luke, T. (2014). Strategic use of evidence during investigative interviews: The state of the science. In D. C. Raskin, C. R. Honts, \& J. C. Kircher (Eds), Credibility assessment: Scientific research and applications (pp. 1-37). Oxford, UK: Academic Press. 
Hartwig, M., Granhag, P.A., \& Strömwall, L.A. (2007). Guilty and innocent suspects' strategies during police interrogations. Psychology, Crime \& Law, 13, $213-$ 227.

Hartwig, M., Granhag, P.A., Strömwall, L.A., \& Vrij, A. (2005). Detecting deception via strategic disclosure of evidence. Law and Human Behavior, 29, 469-484.

Hartwig, M., Granhag, P.A., Strömwall, L.A., Wolf, A., Vrij, A. \& Roos af Hjelmsäter, E. (2011). Detecting deception in suspects: Verbal cues as a function of interview strategy. Psychology, Crime \& Law, 17, 643-656.

Hartwig, M., Granhag, P. A., Strömwall, L. \& Kronkvist, O. (2006). Strate- gic use of evidence during police interrogations: When training to detect deception works. Law and Human Behavior, 30, 603-619.

Hollingshead, A. B. (1998). Retrieval processes in transactive memory sys- tems. Journal of Personality and Social Psychology, 74, 659-671.

Hung, H., Jayagop, D., Yeo, C., Friedland, G., Ba, S., Odobez, J.M., Ramchandran, K., Mirghafori, N., \& Gatica-Perez, D. (2007, September). Using audio and video features to classify the most dominant person in a group meeting. Paper presented at the ACM 15th international conference on Multimedia, New York. Retrieved from: http://www.idiap.ch/ftp/pa- pers/2007/hung-MM-2007.pdf.

Jundi, S., Vrij, A., Hope, L., Mann, S., \& Hillman, J. (2013). Establishing evidence through undercover and collective intelligence interviewing. Psychology, Public Policy, \& Law 19, 297-306. 
Jundi, S., Vrij, A., Mann, S., Hillman, J., \& Hope, L. (under review). 'I'm a photographer, not a terrorist': The use of photography to detect decep- tion. Manuscript under review.

Jundi, S., Vrij, A., Mann, S., Hope, L., Hillman, J., Warmelink, L., \& Gahr, E. (in press). Who should I look at? Eye contact during collective interviewing as a cue to deceit. Psychology, Crime, \& Law.

Kassin, S. M. (2005). On the psychology of confessions: Does innocence put innocent at risk? American Psychologist, 60, 215-228.

Kassin, S. M., \& Gudjonsson, G. H. (2004). The psychology of confessions: A review of the literature and issues. Psychological Science in the Public Interest, 5, 33-67.

Kimery, A. L. (2008, April 29). Airport security: Keep your shoes on and tell the truth. Homeland Security Today. Retrieved from http://www. hstoday.us/index.php?id=483\&cHash=081010\&tx_ttnews[tt_news] =3219

Knieps, M. (2013). True and false intentions: Mental images of the future. Doctoral Dissertation. Department of Psychology. University of Gothenburg. Knieps, M., Granhag, P. A., \& Vrij, A. (2013a). Back to the future: Asking about mental images to discriminate between true and false intentions. The Journal of Psychology: Interdisciplinary and Applied, 147, 619-640. doi:10.1080/00223980.2012.728542.

Knieps, M., Granhag, P. A., \& Vrij, A. (2013b). Repeated visits to the future: Asking about mental images to discriminate between true and false intentions. International Journal of Advances in Psychology, 2, 93-102. 
Loftus, E. F. (2011). Intelligence gathering post-9/11. American Psycholo- gist, $66,532-541$.

Mac Giolla, E. \& Granhag, P.A. (in press). Detecting false intent among small cells of suspects: Single vs. repeated interviews. Journal of Investi- gative Psychology and Offender Profiling.

Mac Giolla, E., Granhag, P. A., \& Ask, K. (2014). Intention related sponta- neous thought: A cue to discriminate between true and false intent. Man- uscript under preparation.

Mac Giolla, E., Granhag, P. A., \& Liu-Jönsson, M. (2013). Markers of good planning behavior as a cue for separating true and false intent. PsyCh Journal. doi: 10.1002/pchj.36.

May, L., Granhag, P.A., \& Oleszkiewicz, S. (2014). Eliciting intelligence using the Scharff-technique: Closing in on the Confirmation/Disconfirmation- tactic. Journal of Investigative Psychology and Offender Profiling, 11, 136-156.

Meijer, E. H., Bente, G. Ben-Shakhar, G., Schumacher, A. (2013). Detecting concealed information from groups using a dynamic questioning approach: Simultaneous skin conductance measurement and immediate feedback. Frontiers in Psychology, 4, 68. DOI: $10.3389 /$ fpsyg.2013.00068

Meijer, E.H., Smulders F.T.Y., Merckelbach, H.L.G.J. (2010). Extracting concealed information from groups. Journal of Forensic Sciences, 55, 6, 1607-1609. DOI: $10.1111 / \mathrm{j} .1556-4029.2010 .01474 . x$ 
Nahari, G., Vrij, A., \& Fisher, R. P. (in press). Exploiting liars' verbal strategies by examining the verifiability of details. Legal and Crimi- nological Psychology.

Nahari, G., Vrij, A., \& Fisher, R. P. (2012). Does the truth come out in the writing? SCAN as a lie detection tool. Law \& Human Behavior, 36, 68-76.

Oleszkiewicz, S., Granhag, P.A. \& Cancino Montecinos, S. (in press). The Scharff-technique: Eliciting intelligence from human sources. Law \& Human Behavior.

Oleszkiewicz, S., Granhag, P.A., \& Kleinman, S.M. (in press). On eliciting intelligence from human sources: Contextualizing the Scharff-technique. Applied Cognitive Psychology.

Redlich, A. D., Kelly, C., \& Miller, J. (2011). Systematic survey of the interview and intelligence community. Final report submitted to the Federal Bureau of Investigation/High-Value Detainee Interrogation Group, Washington, DC.

Redlich, A. D., Kelly, C., \& Miller, J. (in press). The who, what, and why of human intelligence gathering: Self-reported measures of interrogation methods. Applied Cognitive Psychology. DOI: 10.1002/acp.3040.

Russano, M. B., Narchet, F. M., \& Kleinman, S. M. (in press). Analysts, interpreters and intelligence interrogations: Perceptions and insights. Applied Cognitive Psychology.

Russano, M. B., Narchet, F. M., Kleinman, S. M., \& Meissner, C. M. (in press). Structured interviews of experienced HUMINT interrogators. Applied Cognitive 
Psychology.

Sacks, H., Schegloff, E.A., \& Jefferson, G. (1974). A simple systematics for organisation of turn-taking for conversation. Language, 50, 696-735. Schacter, D.L., Addis, D.R., \& Buckner, R.L. (2008). Episodic simulation of future events: Concepts, data and applications. Annals of the New York Academy of Sciences, 1124, 39-60.

Sheeran, P., Milne, S., Webb, T. L., \& Gollwitzer, P. M. (2005). Implementation intentions and health behaviour. In M. Conner \& P. Norman (Eds.), Predicting health behaviour: Research and practice with social cognition models (2nd edn, pp. 276-323). Berkshire, UK: Open University Press.

Sooniste, T., Granhag, P. A., Knieps, M., \& Vrij, A. (2013). True and false intentions: Asking about the past to detect lies about the future. Psychol- ogy, Crime \& Law. doi:10.1080/1068316X.2013.793333.

Sooniste, T., Granhag, P.A., Strömwall, L.A. \& Vrij, A. (in press). Discriminating between true and false intent among small cells of suspects. Legal and Criminological Psychology.

Sooniste, T., Granhag, P. A., Vrij, A., \& Strömwall, L. A., (2014). True and false intention: Using the cognitive interview to magnify the differences. Manuscript submitted for publication.

Soufan, A. H. (2011). The black banners: The inside story of 9/11 and the war against al-Qaeda. New York: W. W. Norton \& Company. 
Strömwall, L. A., Granhag, P. A., \& Hartwig, M. (2004). Practitioners' be- liefs about deception. In P. A. Granhag \& L. A. Strömwall (Eds), Decep- tion detection in forensic contexts (pp. 229-250). Cambridge, England: Cambridge University Press.

Strömwall, L. A., Hartwig, M., \& Granhag, P. A. (2006). To act truthfully: Nonverbal behavior and strategies during a police interrogation. Psychol- ogy, Crime \& Law, 12, 207-219.

Szpunar, K. K. (2010). Episodic future thought: An emerging concept. Perspectives on Psychological Science, 5, 142-162. DOI:10.1177/ 1745691610362350. www.official-documents.gov.uk/document/hc0506/hc10/1087/1087.pdf. Report of the official account of the bombings in London on 7th July 2005. HC 1087. London: The Stationery Office.

Toliver, R. F. (1997). The interrogator: The story of Hans Joachim Scharff master interrogator of the Luftwaffe. Atglen, PA: Schiffer Publishing Ltd.

Vernham, Z., Vrij, A., Leal, S., \& Mann, S. (2014). Collective interviewing: A transactive memory approach towards identifying signs of truthfulness.

Journal of Applied Research in Memory and Cognition, 3, 12-20.

Vernham, Z., Vrij, A., Mann, S., Leal, S., \& Hillman, J. (2014). Collective interviewing: Eliciting cues to deceit using a turn-taking approach.

Psychology, Public Policy and Law. DOI: org/10.1037/law0000015.

Vrij, A., \& Granhag, P. A. (2012). Eliciting cues to deception and truth: What 
matters are the questions asked. Journal of Applied Research in Memory and Cognition, 1, 110-117.

Vrij, A., Granhag, P. A., Mann, S., \& Leal, S. (2011). Lying about flying: The first experiment to detect false intent. Psychology, Crime, and Law, 17, 611-620.

Vrij, A., Granhag, P. A., \& Porter, S. B. (2010). Pitfalls and opportunities in nonverbal and verbal lie detection. Psychological Science in the Public Interest, 11, 89121. DOI: $10.1177 / 1529100610390861$.

Vrij, A., Leal, S., Granhag, P. A., Mann, S., Fisher, R. P., Hillman, J., \& Sperry, K. (2009). Outsmarting the liars: The benefit of asking unantici- pated questions. Law and Human Behavior, 33, 159-166. DOI 10.1007/s10979-008-9143-y.

Vrij, A., Leal, S., Mann, S., \& Fisher, R. (2012). Imposing cognitive load to elicit cues to deceit: Inducing the reverse order technique naturally. Psychology, Crime, \& Law, 18, 579-594.

Vrij, A., Mann, S., Jundi, S., Hope, L., \& Leal, S. (2012). Can I take your picture? Undercover interviewing to detect deception. Psychology, Public Policy, \& Law, 18, 231-244. DOI: $10.1037 / \mathrm{a} 0025670$

Warmelink, L., Vrij, A., Mann, S., \& Granhag, P. A. (in press). Temporal details in intentions: A cue to detecting deception. Applied Cognitive Psychology.

Warmelink, L., Vrij, A., Mann, S., Jundi, S., \& Granhag, P. A. (2012). Have you been there before? The effect of experience and question expectedness on lying about 
intentions. Acta Psychologica., 141, 178-183.

Weaver, M. \& Dodd, V. (2009, April $\left.16^{\text {th }}\right)$ Police delete London tourists' photos 'to prevent terrorism'. www.theguardian.com/uk/2009/apr/16/ police-delete-touristphotos.

Wegner, D. M. (1987). Transactive memory: A contemporary analysis of the group mind. In B. Mullen \& G. R. Goethals (Ed.), Theories of group behaviour (pp. 185208). New York: Springer-Verlag. 